\title{
Connecting environmental education, science-technology-society and ecological theory: possible pathways to reduce socioenvironmental problems
} Conectando educação ambiental, ciência-tecnologia-sociedade e teoria ecológica: caminhos possíveis na redução de problemas socioambientais

Pietro Martins Barbosa Noga ${ }^{1}$ (D), Lia Maris Orth Ritter Antiqueira ${ }^{2}$ (1), Edson Jacinski ${ }^{2}$ (1)

\section{A B S T R A C T}

Social practices influence the production, application, and values of modern Science and Technology (S\&T). The epistemological integration of science, ideology, and politics produces a complexity that is able to restore the capacity of science to deal with complex problems from several levels. Therefore, it is arguable that scientific education should be effectively committed to instrumentalization for citizenship, as well as to avoid misinterpretations, distortions, and social exclusion. This theoretical study aims to provide a useful guideline for teachers, scientists, and decision-makers focusing on the importance of education and general scientific training on conservation efforts, as to encourage the teaching classes to expand the conceptual framework by encompassing the sociopolitical outspread of S\&T. The theoretical foundation was conducted based on two dimensions of Science, Technology, and Society (STS) within scientific education. We created some examples based on phytoplankton biogeochemical dynamics and coral reef conservation to fetch the integration of STS with ecological theory, which can be easily transposed into other subjects or disciplines. The discussion follows the logic that science popularization is a valuable tool for environmental education and a strategy for social inclusion in Brazil. However, the curriculum is an important mechanism driving scholar practices that demands further improvements, besides the academic training of the teachers and the support of the didactic textbooks. Finally, we encourage a policy of science popularization, designed to enlarge individual comprehension of our modern world, to stimulate public participation in decision-making, likewise, to reduce social exclusion and combat structural racism.

Keywords: social inclusion; environmental problems; conservation; socio-scientific controversy.

\section{R E S U M 0}

As práticas sociais influenciam a produção, aplicação e os valores da ciência e tecnologia moderna. A integração epistemológica da ciência, ideologia e política produz uma complexidade que é capaz de restaurar a capacidade da ciência de dialogar com problemas complexos de vários níveis. Por essa razão, argumenta-se que a educação científica deveria ser efetivamente engajada à instrumentalização para a cidadania, bem como para evitar falsas interpretações, distorções e exclusão social. O presente estudo teórico tem por objetivo fornecer um guia útil para professores, cientistas e tomadores de decisão, focando na importância da educação e formação científica em geral nos esforços de conservação, assim como encorajar as salas de aula a expandirem o corpo teórico conceitual pela incorporação dos desdobramentos sociopolíticos da ciência e tecnologia. A fundação teórica foi conduzida baseada nas dimensões da ciência, tecnologia e sociedade na educação científica. Alguns exemplos, baseados na dinâmica biogeoquímica do fitoplâncton e conservação de corais, foram criados buscando a integração de CTS com a teoria ecológica, os quais podem ser facilmente transpostos em outros assuntos e disciplinas. A discussão segue a lógica de que a popularização da ciência é uma ferramenta valiosa para a educação ambiental e uma estratégia para inclusão social no Brasil. Contudo, o currículo é um importante mecanismo na condução das práticas escolares e demanda melhorias, juntamente com a formação acadêmica dos professores e o suporte dos livros didáticos. Finalmente, defende-se uma política de popularização da ciência, desenhada para alargar a compreensão individual do mundo moderno, estimular a participação pública nas tomadas de decisão, reduzir a desigualdade social e combater o racismo estrutural.

Palavras-chave: inclusão social; problemas ambientais; conservação; controvérsias sociocientíficas.

\footnotetext{
${ }^{1}$ Universidade Federal da Bahia - Salvador (BA), Brazil. barbosa@ufba.br

Funding: none.

Received on: 11/30/2020. Accepted on: 06/14/2021.

https://doi.org/10.5327/Z21769478996
}

2Universidade Tecnológica Federal do Paraná - Ponta Grossa (PR), Brazil.

Correspondence address: Pietro Martins Barbosa Noga - Rua Barão de Jeremoabo, s/n - Campus Ondina - Salvador (BA), Brazil. E-mail: pietro.

Conflicts of interest: the authors declare that there are no conflicts of interest.

This is an open access article distributed under the terms of the Creative Commons license. 


\section{Introduction}

Improving scientific teaching has been a major concern in Brazil (El-Hani and Greca, 2013). The traditional practices have been based on contents and concepts that are memorized, decontextualized, or disconnected from reality due to the lack of articulation with the other disciplines of the middle school curriculum (Teixeira, 2003). Science has thus far been a misinterpreted and mistreated body of knowledge wherein complex deep aspects, such as processes, values, interests, and aims, remain neglected or even lost throughout the didactic process (Camino and Calcagno, 1995). Thus, the outcome is likewise an idealization of science disengaged from the real praxis or scientist's labor, implying a mischaracterization of historic battles, contradictions, conflicts, and problems. As a result, a vision of an altruistic, uninterested science arises produced by individuals equally carrying those qualities (Leal and Selles, 1997; Owen et al., 2012, p. 751); whereas, modern Science and Technology (S\&T) play fundamental roles in the organization of social practices, social relationships likewise have "great importance in the production, applications and implications of technology and scientific knowledge" (Campos, 2010, p. 25).

Both the movement and studies on Science, Technology, and Society (STS) originated around the 1970s as a result of efforts to reflect on the impacts that S\&T has on society (Santos and Schnetzler, 1997; Ribeiro et al., 2017). From such a perspective, "war" served as a motto to rethink the euphoria caused by scientific and technological developments adjoined to environmental problems and the advancement of S\&T as a contrary response to the current idea of a neutral and linear scientific progress (González García et al., 1996; Auler and Bazzo, 2001), instead of recognizing the multiscale effects of political decisions on sustainability for a balanced development (Andriantiatsaholiniaina et al., 2004).

The issue of sustainable economic development arises from the ecological movement and the political, economic, and socioenvironmental theme in which humankind and nature theoretically establish harmonic relationships. However, the aforesaid education for sustainability has been criticized regarding its developmental character in which it favors "predatory economic growth," as well as it has overlooked modern global society constraints (Girault and Sauvé, 2008, p. 17; McFarlane and Ogazon, 2011). The original concept of sustainable development, that is, "development that meets the needs of the present generation without compromising the capacity of future generations to meet their own needs" was introduced by the World Commission on Environment and Development (Brundtland, 1985, p. 26; Hanss and Böhm, 2012). The main criticized conceptual issue is that the need for sustainable education goes back to the emergence of environmental problems, because "the world is not as broad and unlimited as we thought” (Vilches et al., 2011, p. 176). Nonetheless, social expressions, such as politics and economics, influence the application of science (Aikenhead, 2006; Camino and Calcagno, 1995), sometimes posing controversial aspects. The importance of such a perception within en- vironmental education relies on the economic aspect of conservation shaped by a sustainability model, along with the production of goods and services that directly affect the environment.

In this context, interdisciplinarity stems as "a logical bridge among fields that converge on the resolution of a given problem" instead of a simple sum of disciplines (Bursztyn and Drummond, 2014, p. 9). The epistemological integration of science, ideology, and politics produces a complexity that is able to restore the capacity of science to deal with complex problems (Morin, 1980; Broggy et al., 2017, p. 81). Several studies on biodiversity conservation within schools adduce a conceptual lag besides a high variety of proposals, methodologies, and practices. Grace and Ratcliffe (2002) observed that the students guide themselves based on their own conceptions, even though biological concepts had been offered with regard to decision-making about conservation scenarios. Grace (2009) introduced biological conservation shedding light onto the social-scientific sphere as a premise toward sustainable development and pedagogical work. Cachelin et al. (2010) attended a textbook-based activity concerning ecology and conservation and indicated that language is one of the main obstacles in the perception of humans acting on ecosystems. Martins and Halasz (2011) analyzed the mangrove conservation of an indigenous area through environmental education within the "Escola no mangue" program.

An alternative to emancipatory and democratic teaching in Brazil originates in Historical-Critical Pedagogy, which establishes connections with the STS movement. These theoretical strands "are excellent instruments of reflection to support change in the focus of scientific education, progressively abandoning the canonical teaching of sciences [...] to build a scientific education approach that is effectively committed to instrumentalization for citizenship," (Teixeira, 2003, p. 179) as for a broader sociopolitical commitment in the application and production of scientific knowledge (Aikenhead, 2006). Studies of STS are crucial to understand and problematize the relationships between STS in the real social practice, as well as to propose forms of informed citizen participation concerning techno-scientific problems.

In this study, we presented a theoretical discussion with the aim to provide a useful guideline for teachers, scientists, and decision-makers by recognizing the importance of education and general scientific training on conservation efforts, as well as to encourage the teaching classes to expand the conceptual framework by encompassing the sociopolitical outspread of S\&T within environmental education. Additionally, we proposed some illustrative examples based on marine ecological communities, whose model can be easily transposed into other formal contents and disciplines.

\section{Methodology}

In order to contemplate the STS framework, the discussion related to scientific education will be carried out alongside the proper epistemological domain over the varied dimensions that STS can denote. 
The first dimension refers to the educational parameters of STS, which "synthesize different perspectives of STS, and may serve to support the insertion of discussions belonging to the field of STS in scientific education" (Strieder and Kawamura, 2017, p. 32). The other dimension is related to the purposes of STS education, which "synthesize different educational perspectives and their meanings in STS education" (Strieder and Kawamura, 2017, p. 32).

Considering the inherent potential of coral reef conservation and phytoplankton ecology in generating multidisciplinary outbreaks, we created several themes, each one accompanied by an introductory text, with the seek to remodel environmental questions from those interconnected dimensions of Science, Technology, Society, and Environment (STSE). These themes also involve different social layers with diverse actors and evoke different potentially controversial problems. The first text introduces the biological entities involved, their role on the ecosystem's properties, and the effects of anthropogenic activities via the degradation or destruction that leads to unbalanced ecosystem functioning. Thus, the proposed examples seek to fetch the integration of STS with coral reefs and phytoplankton ecology as an illustrative background, based on the assumption that the STSE model should incorporate the political component, deconstruct the developmental model, and provide social inclusion.

\section{Results: possible themes and approaches in light of STS}

\section{Why are coral reefs and phytoplankton so important?}

The marine environment is actually the largest ecosystem on Earth. Approximately $70 \%$ of the planet's surface is covered by brackish waters, whose importance is related to reserves of food, oil, natural gas, minerals, and other bioactive substances (Mitra and Zaman, 2016). The oceans hold, among other things, coral reefs and phytoplankton microalgae, which play a crucial role in the biosphere. In the first case, coral reefs account for one-sixth of the world's coastal zone (Birkland, 1997; Chen et al., 2015) and shelter hundreds of thousands of animals and plants species (Reaka-Kudla, 1997).

Anthropogenic activities are responsible for threatening $58 \%$ of coral reefs worldwide (Bryant et al., 1998; Yu, 2012). The main sources of ecosystem disturbance are agriculture, deforestation, and urban development, which introduce high amounts of sediments, nutrients, and pollutants into coastal waters and can lead to eutrophication and habitat destruction (Ginsburg, 1994). During the last few decades, notwithstanding, conservation of coral reefs has been a global concern as those ecosystems are directly affected by climate change (Brandini et al., 2001), which in turn poses a threat to important ecosystem services and ecological dynamics. More than a quarter of coral reefs have already been affected, destroyed, or severely degraded due to problems caused by rising global temperatures (Goreau et al., 2000). For this reason, tropical coral reefs demand high priority for conservation actions (Roberts et al., 2002).
Phytoplankton communities likewise play a crucial role in marine ecosystems and have also been suffering from anthropogenic impacts and neglect from conservation efforts. Anthropogenic activities degrade the phytoplankton ecosystem through excessive exploitation, habitat destruction, and pollution (Lotze et al., 2006; Gunkel et al., 2015), phenomena related to the occupation of coastal areas, where more than $60 \%$ of the global human population is concentrated between the coastline and $100 \mathrm{~km}$ inland (Vitousek et al., 1997). Although representing only $1 \%$ of the Earth's photosynthesizing biomass, the microscopic unicellular organisms that compose this community are responsible for up to $45 \%$ of annual primary productivity (Falkowski et al., 2004). Thus, these organisms are considered a source of energy that sustains trophic chains in pelagic zones, which reflects their importance in global nutrient cycling and dynamics (Cloern and Dufford, 2005).

As a consequence of human development for ecosystems, there has been an inflection pattern in species depletion, destruction of coastal habitats, degradation of water quality, and bioinvasion in coastal ecosystems of North America, Europe, and Oceania over the last 150300 years (Lotze et al., 2006). The social actors related to the problem are coastal communities and consumer society in general. However, agriculture makes a considerable contribution to the degradation of estuarine systems and reservoirs due to the suppression of native land and the introduction of pollutants (Wiegand et al., 2020).

\section{Coral reefs and acidification of coastal waters}

Acidification of coastal waters is one of the factors reported by the scientific community in reference to safe planetary boundaries for global sustainability concerning critical issues arising from human occupation of Earth (Artaxo, 2014). This process is basically caused by carbon dioxide $\left(\mathrm{CO}_{2}\right)$ enrichment of the atmosphere (Hoegh-Guldberg et al., 2007). This increase has not been occurring naturally, since approximately $25 \%$ of the $\mathrm{CO}_{2}$ produced by all human sources enters ocean systems (Canadell et al., 2007) where it reacts with water and produces carbonic acid (Hoegh-Guldberg et al., 2007). This phenomenon decreases carbonate ion concentrations leading to a direct impact on marine organisms that morphologically and physiologically depend on carbonate to build their cells, walls, skeletons, and shells and on ecosystems (Lohbeck et al., 2012; Artaxo, 2014). Although society as a whole contributes to the problem of acidification, some sociotechnical actors are particularly problematic, such as the growing fleet of vehicles powered by fossil fuels and agricultural production with ruminant animals, among other processes that significantly exacerbate the problem.

The relationship between coral reef and acidification of coastal waters, a field of global concern, allows not only environmental classes to summarize empirical concepts of science but also to reflect on how society has related to marine ecosystems historically. This includes the occupation of the Brazilian coast by settlers to the present day during 
which the Anthropocene is by far the most discussed. We proposed an activity consisting of some questions to be discussed after reading a newspaper article about the worldwide threat to coral reefs due to ocean acidification. The questions are as follows:

- What current global phenomena cause ocean acidification?

- Who is responsible for protecting the ocean?

- What human practices contribute to the degradation of marine environments and the consequent death of coral reefs?

- Perform an Internet search of possible toxic effects of sunscreen on marine ecosystems. In brief, report the results and indicate the source of your research.

- What measures should be taken to effectively protect coral reefs? Indicate at least one for each category listed below and their respective associated actors:

- Social responsibility: (e.g., correct disposal of trash - citizens);

- Political responsibility: (e.g., efficient law proposals - politicians);

- Environmental responsibility: (e.g., oversight of threatened areas - environmental police);

- Technological responsibility: (e.g., high-scale monitoring software - scientists).

The fundamental role of the teacher is to guide the students to think of their realities and actions outside of school. Teachers are encouraged to transform the class into a conversation wheel by exploring the news while reminding students about our social, political, and philosophical responsibilities in the face of environmental problems. Similarly, the activity could be extended with participation in a public legislative assembly session on the occasion of debating local issues or law projects.

Technology is also arranged in this way since it is strictly correlated with the transformation of energy and human development. Therefore, the role of the teacher in this example is to lead the students toward a comprehension of the connection between ecological elements and possible STS relationships to be made. Several examples illustrate such relationships, like the discharge of phosphorus via sewage, land use, the effect of sunscreen on coastal waters, and other toxic compounds dumped into the marine environment, pesticide use, conversion of virgin land for agriculture in estuarine ecosystems, and damage to mangroves. Additional possibilities involving different social actors and techno-scientific processes depend on the theme and the specific realities of the school. In our case, examples include industry, ranchers, farmers, fishermen, and the general population that occupies beaches in the summer and introduce high concentrations of chemical compounds from sunscreen that pose a threat to water quality and coastal marine fauna.

\section{Ocean warming}

Global warming is, in fact, one of the main threats that oceans have been facing. In a broad sense, humankind has historically affect- ed, or at least altered, ecosystem functions and/or ecological dynamics since prehistory (Doughty et al., 2010). Nielsen (1960) argued that temperature does not significantly affect marine organic production. However, studies in recent decades have shown that climate change impacts phytoplankton communities by increasing the number of cells and possibly causing the so-called harmful algae blooms (Hallegraeff, 1993). Climate change also poses a threat for coral reefs due to the loss of zooxanthels - photosynthesizing microalgae located in the gastrodermal tissue of coral where they interact symbiotically. Such "abandonment" by zooxanthels leads to coral bleaching and consequent death due to carbonate deficiency likely from acidification or other environmental disturbances (Kikuchi et al., 2004).

Notably, this object of investigation offers a potential background to discuss interdisciplinary implications in terms of the role of STS in environmental issues and how we could solve controversial problems, mainly when they evoke different types of interpretations. For example, market-based relationships between technology and the production of goods and services can be considered from the perspective of the effects of industry on the pollution of the atmosphere, the increasing number of cars that burn fossil fuel, the warming of the planet, and so on.

From another angle, as subjects, coral reefs and phytoplankton may also be efficient at guiding students toward a comprehension of the biosphere as a complex interconnected system, and how sociotechnical actions impact marine life. A student that does not live near the sea or in a coastal region may assume that these marine themes are not common issues to think about. The science teacher is thus entrusted to plan or design environmental classes that dialogue with different social and political spheres enlarging local realities. Furthermore, students may be able to state how human actions impact terrestrial and marine systems on broad scales, especially those derived from economic activities related to consumerism and the production of goods and services (Bursztyn and Drummond, 2014).

Nonetheless, there is a barrier separating citizen participation from the construction of sustainable ideals: the naïve statement or view that environmental changes are linear and slow and thus would allow human adaptation. Apart from such common sense, temperature shifts of around $2^{\circ} \mathrm{C}$ can actually have drastic and irreversible effects on the planet, even though those changes seem to be negligible or of less significance (Pearce, 2007). Such a statement is not always clear or intuitive due to the difficulty of accessing information, as well as the paradoxical character science sometimes achieves. In this example, increased temperature leads to the thawing of the Arctic's permafrost, which implies a release of methane gas and a consequent enhancement of temperature (Vilches et al., 2011). Within our suggested approach, we proposed an activity based on local news regarding coral reef losses over the last 50 years in the Northeast Region of Brazil. Students can be invited to discuss, in pairs or groups, some topics related to the problem mentioned in an STS context. The discussion can then be wide 
open and mediated by the teacher. The main objective of the teacher should be to articulate the activity without personal meddling, yet guide contextualization in order to allow the students to think without losing central information.

\section{Terrestrial runoff and coral reef ecology}

Land use is undoubtedly a major ecological and conservation concern. Coastal regions are being increasingly affected worldwide due to deforestation and the use of fertilizers (Vitousek et al., 1997). More than two decades ago, Bryant et al. (1998) called attention to the increasing nutrient, sediment, and allochthonous pollutant levels to which coastal coral reefs are exposed. Furthermore, the terrestrial runoff was considered an augmenting concern for the majority of 104 countries where coral reefs occur (Bryant et al., 1998).

\section{Discussion}

We presented a narrative that can be applied to any educational reality because the problems addressed are global and emergent, in addition to evidence an unsustainable development increasing chainbased socioenvironmental problems (Andriantiatsaholiniaina et al., 2004). Camino and Calcagno (1995) discussed the same patterns of social implications and controversy in scientific education in Italy and proposed role-playing to solve controversial issues and introduce inter-disciplinary themes of STS. The main argument developed targets the obsolete programs of some countries, where teachers have "little professional preparation to tackle inter-disciplinary themes and are reluctant to introduce environmental issues at school." Hwang (2009, p. 697) addressed "the possibility and practice of environmental education in schools," wherein "the gaps between policy discourse and practice in environmental education have remained significant over the past 20 years". Additionally, the study indicates strict curriculum division and timetable as institutional barriers to environmental education in Korea.

In the light of STS, the acquisition of knowledge and traditional skills cultivated inside science curricula is not enough to be scientifically aware. This may imply the development of attitudes, values, and new skills that support the capacity of formulating and debating responsibly a personal point of view related to scientific-technological problems. (Cachapuz et al., 2002). Such new skills rely on the ethics of responsibility, such as learning how to learn and openness to change. Aside from this, such new skills would sustain "more informed judgments on the merit of certain subjects and situations with personal and/or social implications; participation in the democratic decision-making process; and a better understanding of how ideas of Science/Technology are used in specific social, economic, environmental and technological situations" (Cachapuz et al., 2002, p. 45).

Similarly, teachers should encourage students to think about the scientific content of the curriculum as social-scientific issues by de- constructing the traditional reasoning that S\&T should solve everything, as scientists are responsible for proposing miraculous solutions (Auler and Delizoicov, 2006). Such common sense "encourages the citizenship to delegate to others (the specialists) the responsibility of solutions, justifying its inhibition. This distorts STSE relationships by posing difficulties on solutions to problems" (Vilches et al., 2011, p. 4-5). An example to illustrate this distortion is currently happening in relation to the coronavirus disease-2019 pandemic, due to the public pressure received by scientists, who have been charged with miraculously producing a cure for the virus. Such behavior not only ignores complex scientific processes but also poses unidirectional responsibility, contributing to scientific misinterpretations and assigning values that should be broadly distributed with other important social actors, such as politicians, businesspersons, civil society, large companies, etc.

\section{Popularization of STS as a tool for environmental education}

The history of Conservation Biology illustrates the impossibility of monitoring biodiversity in its entirety, much less when considering its dynamic character. For this reason, ecologists work with indicators or proxies (Williams and Gaston, 1994). Therefore, the term "charismatic" appears in the conservation literature as a specific mark in the identification of emblematic species - in its original definition "popular, charismatic species that serve as symbols and points of a union to simulate conservation actions and consciousnesses" (Heywood and Watson, 1995, p. 23). In spite of their importance, phytoplankton communities have been neglected with regard to conservation efforts. In Brazil, dinoflagellates (unicellular microscopic organisms responsible for toxic or harmful blooms, also called red tides) have remained far less studied than in other countries in the last 50 years, especially when compared with Japan, China, Germany, the United Kingdom, and the United States (Noga and Gomes, 2018).

In this regard, scientific literacy and STS integration raise the possibility of facing environmental issues as interdisciplinary themes, instead of splitting concepts or taxa to study. Such an approach should be applicable to any environmental problem. In fact, the claim is not related to coral reefs or phytoplankton exclusively, but to how responsible science or environmental classes should be performed in order to empower people to be part of scientific and environmental issues, to be capable of decision-making related to STS themes, and to be active and aware toward one's own reality, for example, through political choices. Environmental education has been valued as an educational action that should be present throughout the entire life of a student, in a transversal and/or interdisciplinary way, articulating a set of knowledge and forming attitudes or values and environmental sensitivities (Carvalho, 2017). Therefore, phytoplankton dynamics ecology and coral reefs conservation are good examples to explore the dimensions of STS, but not the point, especially in a developing country where social exclusion historically leads people to be uncommitted to important decisions due 
to a lack of formal education and literacy and misinformation or negligence. Importantly, Brazil has been facing the worst environmental crisis so far due to deforestation (Aragão et al., 2018), fire, lack of public environmental policies, negligence, international disengagement, traditional native communities' abandonment, and ecosystem destruction (Paiva et al., 2020). The Brazilian agency for space research (INPE) has called attention to the increasing fire points and deforestation areas as never seen before and an area up to 3 million acres recently burned in the Wetland-Amazon region during the wettest season, probably caused by illegal occupation to set cattle breeding. Such examples reinforce the necessity of public participation in scientific issues not as a regular student only, but as a citizen able to intervene, understand, and charge politicians to propose better laws and inspections, in addition to consider the scientific information available, instead of denying the problems (i.e., global warming, Amazon fire and deforestation, hundreds of kilometers of coastal areas contaminated by oil in 2019 , etc.).

The set of social practices focused on different aspects of the relationship between society and the environment can be denominated in the environmental field (Carvalho, 2017). The importance of incorporating the social aspect into what is meant by nature or environment is to remove the reductionist character to which some pedagogical practices are subjected. Notwithstanding, teaching practices that enunciate an exclusively naturalistic conception, restricted to fauna, flora, and natural resources conservation are criticized due to the lack of social aspects in their conception. Vilches et al. (2011, p. 171) argued that

it was environmental educators who claimed the protection of the environment - in the broader sense of the human environment, which does not limit their attention to the physical environment, but extends to other social, ethical, cultural, political and economic dimensions - as a basic requirement to make the continuity of the human species possible.

The question remaining is how these dimensions can be efficiently and broadly applied in scientific education in order to achieve a better understanding regarding the human-nature relationships? In this sense, we suggested that scientific popularization should begin in the life of an elementary student and evolve gradually throughout their life. Additionally, scientific academic language should be more accessible to avoid social exclusion and to allow science to dialogue with different dimensions of knowledge, not only the formal dimension. In this sense, "specialization divided the academic world into hundreds of isolated and self-centered fields" (Bursztyn and Drummond, 2014 , p. 4) when, in fact, Science should be the bond to integrate complex epistemological fields in order to restore its capacity to deal with complex problems.
Science popularization as a strategy for social inclusion

The emergence of the environmental agenda since the 20th century has required efforts from various areas and research programs. In the case of scientific education, efforts need to be based on educators to whom appeals are directed toward forming "a citizenship capable of participating in decision-making" (Vilches et al., 2011, p. 4-5). Such an appeal generated positive impacts on an STS educational model and on environmental education "which resulted in an approximation between both currents but led to some misconceptions that need to be undone" (Vilches et al., 2011, p. 5). From this confluence arises an integrated movement involving STS and environmental education, which can be defined, generically, as "educational efforts to make clear to all citizens the seriousness of the problems humanity has to face today and the necessary and possible measures to contribute to their solution" (Vilches et al., 2011, p. 5).

The current context of advances in S\&T is linked to the idea of society's technoscientific illiteracy. Reflections have been generated on the importance of the democratization of acquired knowledge. The label "Scientific and Technological Literacy" encompasses a fairly broad spectrum of meanings translated through expressions such as "popularization of science, scientific dissemination, public understanding of science, and democratization of science" (Auler and Delizoicov, 2001, p. 123). The guiding objectives rely on authentic participation of society in S\&T problem-solving or likewise the endorsement of societal support of the dynamics of current technoscientific development (Auler and Delizoicov, 2001).

Thus, scientific literacy, in addition to science popularization, not only enables critical environmental education but also the entrance into other fields of citizenship that are essential to modern and inclusive life. Lima et al. (2008) argued that a policy of science popularization, designed to enlarge individual comprehension of our modern world, could stimulate public participation regarding choices and directions of S\&T. Consequently, policies of S\&T popularization may contribute to including interests of social groups (i.e., black people, original people, marginalized society, etc.) traditionally left on the sidelines and out of the benefits that scientific and technological development can provide. In this sense, actions to promote the popularization of science can also be understood as strategies to promote social inclusion (Lima et al., 2008).

Notably, the concept of sustainability as the preservation of natural resources for future generations does not include current discrepant socioeconomic realities, especially in Brazil where social inequalities, in addition to structural racism, have led to marginalization, dropping out of school, violence, etc. The World Commission on Environment and Development (1987) mentions a concern for a sustainability that considers social equity, stating that "sustainable development requires the satisfaction of the basic needs of anyone, and extends to all the people the opportunity to satisfy their aspirations for a better life." 
Furthermore, environmental education, the STS movement, and education for sustainability have common objectives, based on the improvement of the quality of life for all, as well as the conservation of the environment in current and future emergencies (Sequinel and Caron, 2010; Vilches et al., 2011). Therefore, the epistemological domain and clarity about the assumptions and articulations of each of these areas are necessary, especially in science classes.

Considering such sociopolitical factors, the science teacher, therefore, has the mission of leading their students under the aegis of the transformation of the reality in which they live, by deconstructing the "scientism" character that "neutralizes/eliminates the subject from the scientific-technological process" and that conveys the idea that "the expert (expert/technician) could solve social problems in an efficient and ideologically neutral way" (Auler and Delizoicov, 2001, p. 124). The critical participation of a student in science, especially in politics and decision-making issues, potentially allows them to ascend as a citizen and provide the social protagonism necessary to reduce social exclusion (Santos, 2012).

\section{Environmental education and curriculum: theoretical basis}

Discussions encircling science curriculum focused on scientific literacy began in the United States of America in the 20th century after changes in the sociocultural scenario (Sasseron and Carvalho, 2011), whereas, an interest was manifested toward a curriculum contemplating impacts on the progress of life, culture, and society, and the rethought programs and curricula worldwide aimed at generating scientists (Hurd, 1998). It was well after that the curriculum began to be thought of according to the need for personal training that accompanies sociohistorical change (Sasseron and Carvalho, 2011). Such conceptual change led to the review of curriculum structure for all students, but not only for those who may want to pursue a scientific career (Hurd, 1998).

The selection of content that integrates the curriculum at the elementary school level seems to have an arbitrary basis when the epistemological foundations to support this selection are not discussed. The State Curriculum Guidelines of Paraná (SCGP) for science teaching propose a discussion related to prescriptive curricular structuralism that does not dialogue with the selection of knowledge historically. Thus, this perspective does not highlight "the way this knowledge is organized and related in the curricular structure and, consequently, the way people can understand the world and act in it" (Paraná, 2008, p. 17).

Based on this criticism, the SCGP document cites three curriculum characterizations, namely:

- academic/scientific curriculum, in which socialized knowledge is "derived from science and the applicability of the scientific method as a teaching method." This type of curriculum, however, makes school subjects hostage to the fragmentation of knowledge, and thus, it does not dialogue and loses the dimension of totality;
- curriculum linked to subjectivity, the main premise of which is the interest or experience of students. This perspective originates in the ideals of the New School and the neoliberal education project implemented in the National Curriculum Parameters. The problems concerning this type of curriculum are that it relies on empirical bases through which the school is reduced to a socializing role, as well as being destitute of the historical character of human knowledge construction;

- curriculum linked to critical theories, i.e., "curriculum as a configurator of practice, a product of broad discussion among the subjects of education, based on critical theories and disciplinary organization."

This perspective considers the various dimensions of knowledge and considers the internal and external factors intrinsic to teaching. Moreover, this disciplinary format allows an interdisciplinary perspective for human knowledge, precisely because of the dialogue-based character it offers (Paraná, 2008).

Of these conceptions, environmental education, sustainability, and conservation are best aligned with the critical theories of the curriculum. However, if elementary school is based on a critical curriculum, then why have some practices not been consolidated therein? We argue that the answer may lie in the teacher through their pedagogical training that, when insufficient, does not correspond to the theoretical curricular foundations on which the school curriculum is rooted. Another possible answer is the textbook in that it may not be in dialogue with the curricular model provided by the official guidelines. The lack of studies concerning methodological issues for addressing biodiversity conservation, such as approaches in the didactic textbooks (Louzada-Silva and Carneiro, 2013), hampers the access and the applications of this agenda on real teaching practices. As a result, the aforesaid critical character of the curriculum is neglected or ineffective. In this case, the textbook becomes a book of texts with general concepts, empty exercises, and a lack of emergent important issues heuristically. Notwithstanding, the formalization of problems related to content and concepts is essential, otherwise "there is no rigorous or scientific discourse about teaching because we would be talking about an empty activity or one with meaning outside the scope of what is it for" (Sacristán, 2000, p. 120).

Thus, environmental education and conservation actions, as scientific knowledge, should start in the school, but they need to transcend its limits, materializing in the daily lives of students, becoming an effect in society, locally where the subject is inserted and where real problems demand public intervention.

\section{Final Considerations}

Science education based on the discussions of STS plays a fundamental role in the conception of critical teaching, citizenship, and environmentally conscious participation. However, there are several 
methodological deficiencies to overcome, whether due to the obsolete academic background of some teachers in relation to the subject or the teaching practice rooted in obsolete textbooks. Therefore, the needs that emerge from these factors are mainly theoretical investments in discussions based on the STS relationships in the teacher training courses (both in graduate academic programs and in continuous pedagogical training) and improvements in textbooks, which should be highly encouraged to include a more coherent look at technoscientific aspects concerning environmental education or STSE.
Research agendas addressing the political and social character of S\&T need to be stimulated, especially in present situation when access to information is increasing. Teacher training courses should also expand discussions on STSE beyond the walls of schools and universities, so as to allow the community, in general, to participate, engage, or make decisions on aspects related to local demands. Demonstrating these relationships is the way that the ecology of coral reefs and phytoplankton can be helpful, in addition to contributing to their biological conservation and showing how to handle controversial social-scientific problems.

\section{Contribution of authors:}

Noga, P.M.B.: Conceptualization, Methodology, Validation, Formal Analysis, Investigation, Writing - Original Draft, Project Administration, Writing Review and Editing. Antiqueira, L.M.O.R.: Conceptualization, Methodology, Validation, Formal Analysis, Investigation, Supervision, Writing - Original Draft, Project Administration, Writing — Review and Editing. Jacinsky, E.: Conceptualization, Visualization, Writing — Review and Editing.

\section{References}

Aikenhead, G.S., 2006. Science education for everyday life: Evidence-based practice. Teachers College Press, Amsterdam.

Andriantiatsaholiniaina, L.A.; Kouikoglou, V.S.; Phillis, Y.A., 2004. Evaluating strategies for sustainable development: fuzzy logic reasoning and sensitivity analysis. Ecological Economics, v. 48, (2), 149-172. https://doi.org/10.1016/j. ecolecon.2003.08.009.

Aragão, L.E.; Anderson, L.O.; Fonseca, M.G.; Rosan, T.M.; Vedovato, L.B.; Wagner, F.H.; Silva, C.V.J.; Silva Junior, C.H.L.; Arai, E.; Aguiar, A.P.; Barlow, J.; Berenguer, E.; Deeter, M.N.; Domingues, L.G.; Gatti, L.; Gloor, M.; Malhi, Y.; Marengo, J.A.; Miller, J.B.; Phillips, O.L.; Saatchi, S., 2018. 21st Century drought-related fires counteract the decline of Amazon deforestation carbon emissions. Nature Communications, v. 9, (1), 536. https://doi.org/10.1038/ s41467-017-02771-y.

Artaxo, P., 2014. Uma nova era geológica em nosso planeta: o Antropoceno? Revista USP, (103), 13-24. https://doi.org/10.11606/issn.2316-9036. v0i103p13-24.

Auler, D.; Bazzo, W.A., 2001. Reflexões para a implementação do movimento CTS no contexto educacional brasileiro. Ciência \& Educação, v. 7, (1), 1-13. https://doi.org/10.1590/S1516-73132001000100001.

Auler, D.; Delizoicov, D. 2001. Alfabetização científico-tecnológica para quê? Ensaio, v. 3, (2), 123-134.

Auler, D.; Delizoicov, D., 2006. Ciência-tecnologia-sociedade: relações estabelecidas por professores de ciências. Revista Electrónica de Enseñanza de las Ciencias, v. 5, (2), 337-355.

Birkland, T.A., 1997. After disaster: Agenda setting, public policy, and focusing events. Georgetown University Press, Washington, D.C.

Brandini, F.P.; Silva, E.T.; Pellizzari, F.M.; Fonseca, A.L.; Fernandes, L.F., 2001. Production and biomass accumulation of periphytic diatoms growing on glass slides during a 1-year cycle in a subtropical estuarine environment (Bay of Paranaguá, southern Brazil). Marine Biology, v. 138(1), 163-171. https://doi. org/10.1007/s002270000427.
Broggy, J.; O’Reilly, J.; Erduran, S., 2017. Interdisciplinarity and science education. In: Taber K.S.; Akpan B. (Ed.), Science Education. Brill Sense, Rotterdam, pp. 81-90.

Brundtland, G.H., 1985. World commission on environment and development. Environmental Policy and Law, v. 14, (1), 26-30.

Bryant, D.; Burke, L.; McManus, J.; Spalding, M., 1998. Reefs at risk: a mapbased indicator of potential threats to the world's coral reefs. World Resources Institute, Washington, D.C.

Bursztyn, M.; Drummond, J., 2014. Sustainability science and the university: pitfalls and bridges to interdisciplinarity. Environmental Education Research, v. 20, (3), 313-332. https://doi.org/10.1080/13504622.2013.780587.

Cachapuz, A.; Praia, J.; Jorge, M., 2002. Ciência, educação em ciência e ensino das ciências. Temas de Investigação. Ministério da Educação, Lisboa.

Cachelin, A.; Norvell, R.; Darling, A., 2010. Language fouls in teaching ecology: Why traditional metaphors undermine conservation literacy. Conservation Biology, v. 24, (3), 669-674. https://doi.org/10.1111/ j.1523-1739.2010.01481.x.

Camino, E.; Calcagno, C., 1995. An interactive methodology for "empowering" students to deal with controversial environmental problems. Environmental Education Research, v. 1, (1), 59-74. https://doi. org/10.1080/1350462950010105.

Campos, F.R.G., 2010. Ciência, tecnologia e sociedade. IFSC, Florianópolis.

Canadell, J.G.; Le Quéré, C.; Raupach, M.R.; Field, C.B.; Buitenhuis, E.T.; Ciais, P.; Conway, T.J.; Gillett, N.P.; Houghton, R.A.; Marland, G., 2007. Contributions to accelerating atmospheric $\mathrm{CO} 2$ growth from economic activity, carbon intensity, and efficiency of natural sinks. Proceedings of the National Academy of Sciences, v. 104, (47), 18866-18870. https://doi. org/10.1073/pnas.0702737104.

Carvalho, I.C.N., 2017. Educação ambiental: a formação do sujeito ecológico. Cortez, São Paulo. 
Chen, P.Y.; Chen, C.C.; Chu, L.; McCarl, B., 2015. Evaluating the economic damage of climate change on global coral reefs. Global Environmental Change, v. 30, 12-20. https://doi.org/10.1016/j.gloenvcha.2014.10.011.

Cloern, J.E.; Dufford, R., 2005. Phytoplankton community ecology: principles applied in San Francisco Bay. Marine Ecology Progress Series, v. 285, 11-28. https://doi.org/10.3354/meps285011.

Doughty, C.E.; Wolf, A.; Field, C.B., 2010. Biophysical feedbacks between the Pleistocene megafauna extinction and climate: the first human-induced global warming? Geophysical Research Letters, v. 37, (15). https://doi. org/10.1029/2010GL043985.

El-Hani, C.N.; Greca, I.M., 2013. ComPratica: a virtual community of practice for promoting biology teachers' professional development in Brazil. Research in Science Education, v. 43, (4), 1327-1359. https://doi.org/10.1007/ s11165-012-9306-1.

Falkowski, P.G.; Katz, M.E.; Knoll, A.H.; Quigg, A.; Raven, J.A.; Schofield, O.; Taylor, F.J.R., 2004. The evolution of modern eukaryotic phytoplankton. Science, v. 305, (5682), 354-360. https://doi.org/10.1126/science.1095964.

Ginsburg, R.N. (Ed.), 1994. Proceedings of the colloquium on global aspects of coral reefs, health, hazards and history. Atlantic Reef Committee, Miami.

Girault, Y.; Sauvé, L., 2008. Léducation scientifique, léducation à lenvironnement et léducation pour le développement durable. Croisements, enjeux et mouvances. Aster, (46). https://doi.org/10.4267/2042/20028.

González García, M.I.; Luján López, J.L.; López Cerezo, J.A., 1996. Ciencia, tecnología y sociedad: una introducción al estudio social de la ciencia y la tecnologia. Tecnos, Madrid.

Goreau, T.; McClanahan, T.; Hayes, R.; Strong, A.L., 2000. Conservation of coral reefs after the 1998 global bleaching event. Conservation Biology, v. $14,(1), 5-15$.

Grace, M.M. (2009). Developing high quality decision-Making discussions about biological conservation in a normal classroom setting. International Journal of Science Education, v. 31, (4), 551-570. https://doi. org/10.1080/09500690701744595.

Grace, M.M.; Ratcliffe, M., 2002. The science and values that young people draw upon to make decisions about biological conservation issues. International Journal of Science Education, v. 24, (11), 1157-1169. https://doi. org/10.1080/09500690210134848.

Gunkel, G.; Matta, E.; Selge, F.; Silva, G.M.N.; Carmo Sobral, M., 2015. Carrying capacity limits of net cage aquaculture in Brazilian reservoirs. Brazilian Journal of Environmental Sciences (Online), (36), 128-144. https:// doi.org/10.5327/Z2176-947820151008.

Hallegraeff, G.M., 1993. A review of harmful algal blooms and their apparent global increase. Phycologia, v. 32, (2), 79-99. https://doi.org/10.2216/i00318884-32-2-79.1.

Hanss, D.; Böhm, G., 2012. Sustainability seen from the perspective of consumers. International Journal of Consumer Studies, v. 36, (6), 678-687. https://doi.org/10.1111/j.1470-6431.2011.01045.x.

Heywood, V.H.; Watson, R.T., 1995. Global biodiversity assessment. Cambridge University Press, Cambridge, v. 1140.

Hoegh-Guldberg, O.; Mumby, P.J.; Hooten, A.J.; Steneck, R.S.; Greenfield, P.; Gomez, E.; Harvell, C.D.; Sale, P.F.; Edwards, A.J.; Caldeira, K.; Knowlton, N.; Eakin, C.M.; Iglesias-Prieto, R.; Muthiga, N.; Bradbury, R.H.; Dubi, A.; Hatziolos, M.E., 2007. Coral reefs under rapid climate change and ocean acidification. Science, v. 318, (5857), 1737-1742. https://doi.org/10.1126/ science.1152509.
Hurd, P.D., 1998. Scientific literacy: new minds for a changing world. Science Education, v. 82, (3), 407-416. https://doi.org/10.1002/(SICI)1098237X(199806)82:3\%3C407::AID-SCE6\%3E3.0.CO;2-G.

Hwang, S., 2009. Teachers' environmental education as creating cracks and ruptures in school education: A narrative inquiry and an analysis of teacher rhetoric. Environmental Education Research, v. 15, (6), 697-714. https://doi. org/10.1080/13504620903380771.

Kikuchi, R.K.P.; Leão, Z.M.A.N.; Oliveira, M.D.; Dutra, L.X.; Cruz, I.C., 2004. Branqueamento de corais nos recifes da Bahia associado aos efeitos do El Niño 2003. In: Congresso de Planejamento e Gestão das Zonas Costeiras dos Países de Expressão Portuguesa, 2, 213.

Leal, M.C.; Selles, S.E., 1997. Sociologia e ensino de ciências: anotações para discussão. In: Encontro Nacional de Pesquisa em Educação em Ciências, 1, Águas de Lindóia. pp. 338-344.

Lima, M.T.; das Neves, E.F.; Dagnino, R., 2008. Popularização da ciência no Brasil: entrada na agenda. Journal of Science Communication, 7, 4.

Lohbeck, K.T.; Riebesell, U.; Reusch, T.B., 2012. Adaptive evolution of a key phytoplankton species to ocean acidification. Nature Geoscience, v. 5, (5), 346351. https://doi.org/10.1038/ngeo1441.

Lotze, H.K.; Lenihan, H.S.; Bourque, B.J.; Bradbury, R.H.; Cooke, R.G.; Kay, M.C.; Kidwell, S.M.; Kirby, M.X.; Peterson, C.H.; Jackson, J.B., 2006. Depletion, degradation, and recovery potential of estuaries and coastal seas. Science, v. 312, (5781), 1806-1809. https://doi.org/10.1126/science.1128035.

Louzada-Silva, D.; Carneiro, M.H.D.S., 2013. A conservação da natureza em livros didáticos de Biologia. In: Encontro Nacional de Pesquisa em Educação em Ciências, 9. pp. 1-8.

Martins, C.; Halasz, M., 2011. Educação ambiental nos manguezais PiraquêAçú e Piraquê-Mirim. Brazilian Journal of Environmental Sciences (Online), (19), 11-17.

McFarlane, D.A.; Ogazon, A.G., 2011. The challenges of sustainability education. Journal of Multidisciplinary Research (1947-2900), v. 3, (3), 81-107.

Mitra, A.; Zaman, S., 2016. Basics of marine and estuarine ecology. Springer, New Delhi.

Morin, E., 1980. O método 2: a vida da vida. Publicações Europa-América, Sintra.

Nielsen, E.S., 1960. Dark fixation of CO2 and measurements of organic productivity. With remarks on chemo-synthesis. Physiologia Plantarum, v. 13, (2), 348-357. https://doi.org/10.1111/j.1399-3054.1960.tb08037.x.

Noga, P.M.B.; Gomes, D.F., 2018. Scientometrical review of Dinoflagellate studies in Brazil. Acta Botanica Brasilica, v. 32, (4), 503-510. https://doi. org/10.1590/0102-33062017abb0376.

Owen, R.; Macnaghten, P.; Stilgoe, J., 2012. Responsible research and innovation: from science in society to science for society, with society. Science and Public Policy, v. 39, (6), 751-760. https://doi.org/10.1093/scipol/scs093.

Paiva, P.F.P.R., Ruivo, M.D.L.P., Silva Junior, O.M., Maciel, M.D.N.M., Braga, T.G.M., Andrade, M.M.N., Santos Junior, P.C.S.; Rocha, E.S.; Freitas, T.P.M.; Leite, T.V.S.; Gama, L.H.O.M.; Santos, L.S.; Silva, M.G.; Silva, E.R.R.; Ferreira, B.M., 2020. Deforestation in protect areas in the Amazon: a threat to biodiversity. Biodiversity and Conservation, v. 29, (1), 19-38. https://doi. org/10.1007/s10531-019-01867-9.

Paraná, 2008. Diretrizes Curriculares da Rede Pública de Educação Básica do Estado do Paraná. Curitiba, Secretaria de Estado da Educação.

Pearce, F., 2007. La última generación. Barrabes Editorial, Benasque (Huesca). 
Reaka-Kudla, M.L., 1997. The global biodiversity of coral reefs: a comparison with rain forests. In: Reaka-Kudla, M.; Wilson, D.E.; Wilson, E.O. (Ed.), Biodiversity II: understanding and protecting our biological resources. Joseph Henry Press, Washington, D.C., pp. 83-108.

Ribeiro, T.V.; Santos, A.T.; Genovese, L.G.R., 2017. A história dominante do movimento CTS e o seu papel no subcampo brasileiro de pesquisa em ensino de ciências CTS. Revista Brasileira de Pesquisa em Educação em Ciências, v. 17, (1), 13-43. https://doi.org/10.28976/1984-2686rbpec201717113.

Roberts, C.M.; McClean, C.J.; Veron, J.E.; Hawkins, J.P.; Allen, G.R.; McAllister, D.E.; Mittermeier, C.G.; Schueler, F.W.; Spalding, M.; Wells, F.; Vynne, C.; Werner, T.B., 2002. Marine biodiversity hotspots and conservation priorities for tropical reefs. Science, v. 295, (5558), 1280-1284. https://doi. org/10.1126/science.1067728.

Sacristán, J.G., 2000. O currículo: uma reflexão sobre a prática. 3. ed. Artmed, Porto Alegre.

Santos, W.L.P., 2012. Educação CTS e cidadania: confluências e diferenças. Amazônia: Revista de Educação em Ciências e Matemáticas, v. 9, (17), 49-62.

Santos, W.L.P.; Schnetzler, R.P., 1997. Educação em Química: compromisso com a cidadania. Ijuí: Editora Unijuí.

Sasseron, L.H.; Carvalho, A.M.P., 2011. Alfabetização científica: uma revisão bibliográfica. Investigações em Ensino de Ciências, v. 16, (1), 59-77.

Sequinel, M.C.; Caron, A., 2010. Consumo sustentável: uma questão educacional e de múltiplas responsabilidades. Brazilian Journal of Environmental Sciences (Online), (16), 36-43.
Strieder, R.B.; Kawamura, M.R.D. 2017. Educação CTS: parâmetros e propósitos brasileiros. Alexandria, v. 10, (1), 27-56. https://doi. org/10.5007/1982-5153.2017v10n1p27.

Teixeira, P.M.M., 2003. A educação científica sob a perspectiva da pedagogia histórico-crítica e do movimento CTS no ensino de ciências. Ciência \& Educação, v. 9, (2), 177-190. https://doi.org/10.1590/S151673132003000200003 .

Vilches, A.; Gil-Pérez, D.; Praia, J., 2011. De CTS a CTSA: educação por um futuro sustentável. In: Santos, W.L.P.; Auler, D. (Ed.)., CTS e Educação científica: desafios, tendências e resultados de pesquisa. Editora da UnB, Brasília, pp. 161-184.

Vitousek, P.M.; Mooney, H.A.; Lubchenco, J.; Melillo, J.M., 1997. Human domination of Earth's ecosystems. Science, v. 277, (5325), 494-499. https://doi. org/10.1126/science.277.5325.494.

World Commission on Environment and Development. 1987. Our common future, v. 17, (1), 1-91.

Wiegand, M.; Nascimento, A.T.; Costa, A.; Lima Neto, I.E., 2020. Evaluation of limiting nutrient of algal production in reservoirs of the Brazilian semiarid. Brazilian Journal of Environmental Sciences (Online), v. 55, (4), 456-478. https://doi.org/10.5327/Z2176-947820200681.

Williams, P.H.; Gaston, K.J., 1994. Measuring more of biodiversity: can highertaxon richness predict wholesale species richness? Biological Conservation, v. 67, (3), 211-217. https://doi.org/10.1016/0006-3207(94)90612-2.

Yu, K., 2012. Coral reefs in the South China Sea: Their response to and records on past environmental changes. Science China Earth Sciences, v. 55, (8), 12171229. https://doi.org/10.1007/s11430-012-4449-5. 